\title{
Oxytocin; Effects on Milk Production
}

\author{
Muhammad Ahmad ${ }^{1}$, Ghulam Jelani ${ }^{1}$, Shaista Jalbani $^{2 *}$ and Majid \\ Hussain Soomro ${ }^{3}$ \\ 1. Department of Veterinary and Biosciences, Shaheed Benazir Bhutto University of Veterinary and Animal \\ Sciences, Sakrand-Pakistan \\ 2. Department of Fisheries and Aquaculture, Shaheed Benazir Bhutto University of Veterinary and Animal Sciences, \\ Sakrand-Pakistan \\ 3. Department of Veterinary Parasitology, Shaheed Benazir Bhutto University of Veterinary and Animal Sciences, \\ Sakrand-Pakistan \\ *Corresponding author's email: jalbanishaista@gmail.com
}

Citation

Muhammad Ahmad, Ghulam Jelani, Shaista Jalbani and Majid Hussain Soomro. Oxytocin; Effects on milk production. Pure and Applied Biology. Vol. 10, Issue 1, pp318-324. http://dx.doi.org/10.19045/bspab.2021.100034

\begin{tabular}{llll}
\hline \hline Received: 11/06/2020 & Revised: 24/08/2020 & Accepted: 31/08/2020 & Online First: 21/09/2020
\end{tabular}

\section{Abstract}

Oxytocin (OT) (quick birth) is a polypeptide hormone that is released and stored in the posterior pituitary gland. It is used in veterinary practices for the milk let down and for the treatment of certain diseases like mastitis but in Pakistan it is used for the increase of milk production. OT injection is easily available in the village shops and large number of farmers uses OT for the increase of milk production but most researches shows that milk flow is increase by the OT administration. Whereas some authors state that small amount of milk production increases by administration of OT that is $10-15 \%$. Regular use of OT has many harmful effects on the animals and the human beings that used milk of OT used animals. It causes loss of hair, stunted growth, less productivity of the animals and failure of the reproductive organs etc. So it should be sale on the veterinarian prescription and properly guide the farmers about OT.

Keywords: Abuses; Hormone; Milk; Pakistan; Uses

\section{Introduction}

OT is a peptide hormone that is released from the posterior pituitary. The release of OT from the posterior pituitary is regulated by sensory stimuli rising from the cervix, vagina and suckling of the milk reflux from the mammary gland. Stimulation of cervix in the pregnant animal elicits a nervous signal to hypothalamus cause secretion of the OT, suckling stimuli of nipple/teat release of OT by same route. It is also known as alpha hypophamine [1]. Large amount of the milk is store in alveoli and small milk ducts of the udder that is transferred to the cisternal cavities by the neuroendocrine reflux by OT to make milk
$[2,3]$. Oxytocin is released by the stimulation of teats from the pituitary gland. It contracts the myoepithelial cells around the alveoli and small milk ducts of udder. Then milk is transferred into the mammary ducts, cisternal cavities of the gland and teats [4].

The synthetic OT is used in the worldwide and in our country (Pakistan) that is approved by Food and Drug Administration Act (FDA). It is used frequently with the aim of preventing postpartum bleeding, therapeutic aborts, and parturition induction, providing postpartum lactation that is increasing now a day [5-7]. In United States (US) OT for all parturition was used $18.4 \%$ 
and this rate was stated as $20 \%$ in 2000 [8]. OT is injected in animals before or during the milking that remove total amount of residual milk because all the milk is not removed from udder. By the use of the OT up to $90 \%$ milk is removed from the udder by the normal milking [9]. Long-term use of exotic OT reduces the milk production [10]. OT injection effect on the magnitude of milk production that is variable from 10 to 15.5 $\%$. Dosage and time of OT injection control the Milk production [11]. In Pakistan OT is used on large scale for the milk production or increase milk yield because it can be purchased without any prescription and available easily on fewer prices $[12,13]$.

\section{Mechanism of action}

OT is a nano-peptide hormone stored particularly in pars nervosa or posterior lobe of pituitary gland and it is one of the few hormone that have positive feedback on the stimulation action. OT causes $\mathrm{g}$ protein coupled to stimulate by arising intra cellular calcium in uterine myofibril. This is where positive feedback comes to play when OT is raised it causes the uterine contraction and these contraction further ore increases the OT level. When fetus pusses again cervix it impulses the release of the OT in much amount and thus consumption is completely successful. Not only OT cause uterine contraction but it causes myoepithelial cells in the female breast to squeeze. Such contraction force milk expulsion hence positive feedback is revealed (Fig. 1). When infant suck the mother breast it stimulates the release of OT and milk let down. Less of this hormone will be released as it exhibited it effect on the body $[14,15]$.

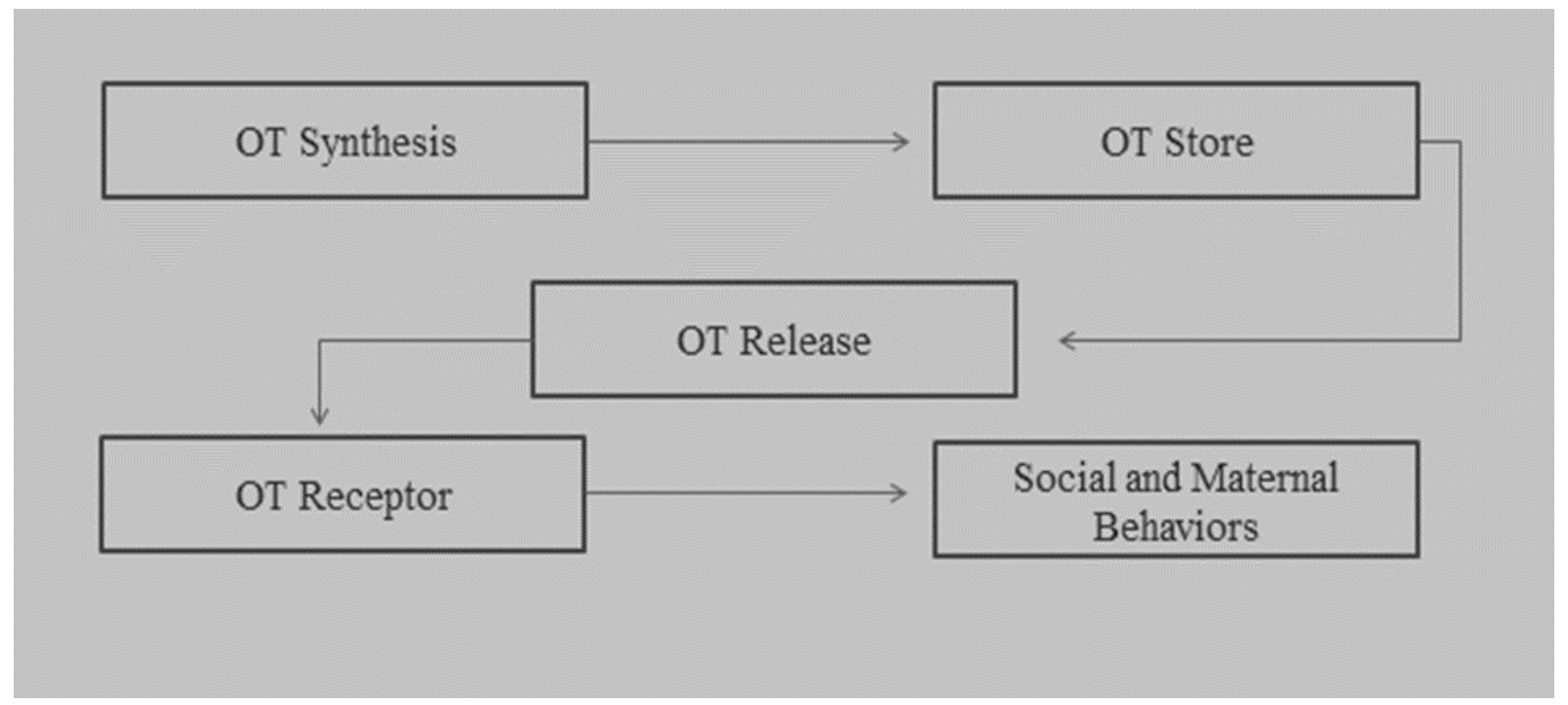

Figure 1. Mechanism of oxytocin

\section{Use of the Oxytocin (\%) in Pakistan}

Use of OT increases the milk production in buffalo and cattle that is $96.66 \%$ and $90 \%$ respectively and OT is used for the dead fetus and difficult birth in cattle and buffaloes (Table 1) [12].

\section{Use of the Oxytocin on dairy farms for milk production in Pakistan}

It was observed that OT could easily be purchased for as little

e as $18-20$ rupees $/ 50 \mathrm{ml}$ from local shops, even at village level (Fig. 2) [16]. 
Table 1. Oxytocin Uses in Pakistan

\begin{tabular}{|c|c|c|c|}
\hline Specie & Milk yield\% & Dead fetus\% & Difficulty in birth\% \\
\hline Cattle & 90 & 10 & 58.33 \\
\hline Buffalo & 96.66 & 13.33 & 71.66 \\
\hline
\end{tabular}

\section{Average \% use of OT}

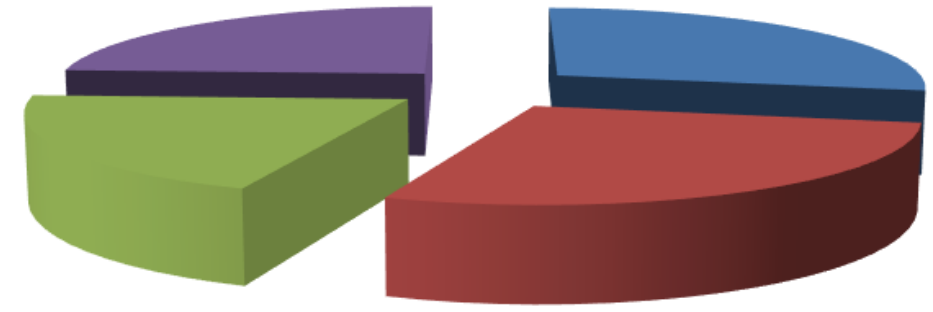

- Small scale dairy farmers

- Large scale dairy farmers

- Semi commercial small dairy farmers

- Semi commercial dairy farmers

Figure 2. Use of Oxytocin uses in farms

\section{Uses of the OT}

OT injection is used to let milk down in the buffaloes and cows [17]. For milk let down many ways are used like calf suckling, manual pre-stimulation, feeding of concentrates and OT injection is also used for the milking [18]. According to the Indian survey it is estimated that $65 \%$ surveyed farm use concentrates feeding and 13\% farms use OT injection for the milk let down .In Pakistan concentrate feeding, calf suckling and injection of the OT are used for the stimulation of the dairy animals [19-21]. Administration of the small dose of OT can increase or have no effect on the milk production, while administration in large amount increases the milk yield $15.5 \%$ whatever on the removal of complete milk. Every research show different effect of the OT injection but according to the Nostrand and their colleagues in 1991 showed that by the administration of OT $10-12 \%$ milk production increases while some researches show no significant effect on the milk production [22]. OT is used for the increase of milk production in the dairy cows. Milk production increases significantly but the fat $\%$ in the milk does not change as shown in (Table 2) [23].

OT helps in the transport of egg and sperms by the muscle contraction [24]. It helps to decrease the excretion of urine due to its similarity with vasopressin and stimulates the excretion of sodium from kidney [25] and helps to mediate aggressive behavior in sheep. OT excreted during stress [26] and it is a significant modulator during the anxiety and fear by acting on the amygdale [27]. It increased positive communication, reduces stress and improve health in positive couple 
interaction [28]. It may also increase the classical stress hormone of the hypothalamus pituitary adrenal axis $[29,30]$. OT inhibits excitatory flow from amygdala to brainstem sites by acting on the central amygdala to mediating fear response [31]. OT reduces feeding and acts as a satiety hormone in animal [32] and it also decrease the level of fat in body by increasing lipolysis [33].

Administration of OT in sheep helps in the transcervical artificial insemination [34]. During the treatment of mastitis it is also used to remove the debris of udder and milk reduce [35]. OT produces attraction between male and female.

OT administration in large quantity for one week increases milk production $15.5 \%$ while applying OT for 2 weeks increase in the milk production is only $3 \%$ [36].OT universally used to produce letdown of milk in veterinary practice.

OT acts on the uterus and mammary gland of female reproduction. Its synthetic analogues are carbotocin and demoxytocin that are used in obstetrics for the prevention of puerperal mastitis and to decrease the postpartum bleeding after parturition. It is also used for the induction of labor and also reduces bleeding after abortion [37]. Penile erection is the most important for sexual reproduction which is induced by oxytocin [38]. OT helps in the dilation of the cervix and causes the contraction of the uterus during the $2^{\text {nd }}$ and $3^{\text {rd }}$ stage of the labor [24]. Oxytocin hormone is also known as love hormone [39]. Oxytocin secretion increases during the sleeping in humans. Oxytocin lessens the fear by inhibiting the amygdale [40]. It also effects on the behavior, learning and memory. The administration of the OT increases the milk production with the greater maintenance of the persistency during the lactation [22].

On the other hand, there's proof from the literature that the momentary treatment of buffaloes with OT to ease birth or placenta elimination increased the productive performance of buffaloes via decreasing involution time and service period [41]. Armstrong and Hansel, 1959 concluded that OT may influence estrous cycle period of cow [42]. As Afzal reported in 2003 the impact of long-term utilization of OT in buffaloes are unknown [43].

Table 2. Effect of the Oxytocin on the milk composition and their production

\begin{tabular}{|c|c|c|c|c|c|c|}
\hline Authors & Time duration & Milk yield & $\begin{array}{c}\text { Lactose } \\
\mathbf{\%}\end{array}$ & Fat \% & $\begin{array}{c}\text { Protein } \\
\text { \% }\end{array}$ & $\begin{array}{c}\text { Total } \\
\text { solids \% }\end{array}$ \\
\hline $\begin{array}{c}\text { Natzke and } \\
\text { Schultz, 1967 } \\
\text { [35] }\end{array}$ & Post treatment & $2.52(\mathrm{Kg} / \mathrm{qtr})$ & 4.82 & 3.23 & 3.32 & - \\
\hline $\begin{array}{c}\text { Abbas \& Zahoor } \\
\text { 2014 [44] }\end{array}$ & Fortnight & - & 5.09 & 3.65 & 3.50 & - \\
\cline { 2 - 7 } & Month & - & 5.21 & 4.70 & 3.59 & - \\
\hline $\begin{array}{c}\text { Alkass } \text { et al., } \\
\text { 2012 [45] }\end{array}$ & - & $229.10 \mathrm{ml}$ & 4.48 & 5.06 & 5.42 & 15.81 \\
\hline $\begin{array}{c}\text { Sprain } \text { et } \\
\text { al.,1954 [46] }\end{array}$ & $\begin{array}{c}\text { After 14 day of } \\
\text { experiment }\end{array}$ & $43.8 \mathrm{Ib}$ & - & 3.41 & - & - \\
\hline \multirow{2}{*}{$\begin{array}{c}\text { Ballouet al., } \\
\text { 1993 [36] }\end{array}$} & 95 days & $30.89 \mathrm{~kg}$ & 4.79 & 3.56 & 3.22 & - \\
\cline { 2 - 7 } & $\begin{array}{c}\text { Oxy. Inj. before } \\
\text { milking }\end{array}$ & $29.2 \mathrm{~kg}$ & 4.77 & 3.53 & 3.20 & - \\
\cline { 2 - 7 } & Oxy. Inj. after milking & $29.3 \mathrm{~kg}$ & 4.78 & 3.44 & 3.17 & - \\
\hline
\end{tabular}




\section{Abuses}

Use of the exotic OT changes the $\mathrm{pH}$, fat, lactose and protein value of milk as compared to milk of other animals. In Pakistan OT inj. is used intra muscularly by the farmer without the prescription of veterinarian and face loss of the production and reproductive performance of the animal [12]. By the administration that milk fat content is reduced but fatty acid composition remains same.

Regular use of the OT in buffalo and cattle cause reproductive disorders that are repeated estrus, luteal cyst, retention of placenta, follicular ovarian cysts $[12,20 \&$ 47]. It also raptures the corpus luteum before the time [48].

Delayed puberty, low conception rate, dead fetus, difficult birth and incidence of abortion are shown in the calves that used OT milk [49]. OT injection has harmful effects like breast cancer, carcinogenic growth, hair loss and stunted growth [50].

Vegetable growers believed that OT increases their production therefore they used the OT in the fruits and vegetables and largely used in the water melons [51].

It is reported that in India hundreds of the girls kidnapped and then OT injection is administrated so that they reach their puberty soon and then these girls are pushed into the prostitutions [51]. OT causes the water intoxication that is characterized by the weight gain, loss of appetite, nausea and vomiting. It also affects the uterus, fetal injury and can also affect the heart failure, seizure and even death can occur by the excess administration [32]. To decrease the level of OT medication Atosiban is used.

\section{Conclusion}

It was concluded from present study that farmers used OT without the veterinarian advice that results in the decrease of production and also effect reproductive organs of the animals. The ingredients of drug excrete out through the milk that pass into milk user like humans that cause the breast cancer, loss of hair, stunted growth and early maturation. The regular uses of the OT in the animals cause the difficulty in birth and also decrease the quality of milk. It is used for increase the milk production. But present study shows that OT is very harmful so it should be sold with veterinarian prescription and used only for treatment not for the increase of the milk production. It is necessary to guide the farmers about the side effects of the OT.

\section{Authors' contributions}

Conceived and designed the experiments: S Jalbani \& MH Soomro, Performed the experiments: M Ahmad \& G Jelani, Analyzed the data: S Jalbani \& MH Soomro, Contributed materials/ analysis/ tools: $\mathrm{M}$ Ahmad \& S Jalbani, Wrote the paper: M Ahmad \& G Jelani.

\section{Reference}

1. Katzung BG \& Trevor AJ (Eds.) (2015). New York: McGraw-Hill Education. Basic \& Clinical Pharmacol 619-620.

2. Knight CH, Hirst D \& Dewhurst RJ (1994). Milk accumulation and distribution in the bovine udder during the interval between milkings. J Dairy Res 61(2): 167-177.

3. Bruckmaier RM \& Blum JW (1998). Oxytocin release and milk removal in ruminants. J Dairy Sci 81(4): 939-949.

4. Bruckmaier RM, Schams D \& Blum J W (1994). Continuously elevated concentrations of oxytocin during milking are necessary for complete milk removal in dairy cows. J Dairy Res 61(3): 323-334

5. Stubbs TM (2000). Oxytocin for labor induction. Clin Obs Gyn 43(3): 489-94.

6. Shyken JM \& Petrie RH (1995). The use of oxytocin. Clin Perin 22(4): 907-931.

7. Nichols FH \& Welling E (1997). Maternalnewborn nursing: Theory and practice. London: WB Saunders.

8. Willcourt RJ, Pager D, Wendel J \& Hale RW (1994). Induction of labor with pulsatile oxytocin by a computer-controlled ump. American J Obst Gyn 170(2): 603608. 
9. Dzidic A, Macuhova J, \& Bruckmaier RM (2004). Effects of cleaning duration and water temperature on oxytocin release and milk removal in an automatic milking system. J Dairy Sci 87(12): 4163-4169.

10. Bruckmaier RM (2003). Chronic oxytocin treatment causes reduced milk ejection in dairy cows. J Dairy Res 70(1): 123-126.

11. Borghese A, Rasmussen M \& Thomas CS (2007). Milking management of dairy buffalo. Italian J Anim Sci 6(Sup2): 39-50.

12. Mustafa MY, Saleem K, Munir R \& Butt TM (2008). Effect of oxytocin on the productive and reproductive performance of buffalo and cattle in Sheikhupura-Pakistan (A field study). Vet 9: 45.

13. Ijaz A \& Aleem M (2006). Exogenous Administration of oxytocin and its residual effects. Pak Vet J 26(2): 99-100.

14. Kimura T, Tanizawa, O, Mori K, Brownstein MJ \& Okayama H (1992). Structure and expression of a human oxytocin receptor. Nature 356(6369): 526529.

15. Ellis JA, Brown CM, Barger B \& Carlson NS (2019). Influence of maternal obesity on labor induction: a systematic review and meta-analysis. J Mid Women's Heal 64(1): 55-67.

16. Tariq $M$ \& Younas $M$ (2013). Use of Oxytocin and Milking Management of Buffaloes in (Urban) Peri-Urban Area of Faisalabad. Editorial Board 1155.

17. Belo CJ \& Bruckmaier RM (2010). Suitability of low-dosage oxytocin treatment to induce milk ejection in dairy cows. J Dairy Sci 93(1): 63-69.

18. Thomas CS (2004). Milking Management of dairy buffaloes. PhD thesis SLU Sweden 455. https://www.researchgate.net/project/Ph.

19. Bilal MO, Hameed A \& Khan BB (2008). Assessment of dairy farm management practices under field conditions of Toba Tek Singh. Pak J Agric Sa 45: 2.

20. Qureshi M \& Ahmad N (2008). Interaction among calf suckling, use of oxytocin, milk production and reproduction in dairy buffaloes. J Ani Repr Sci 106(3-4): 380392.

21. Khan TH, Beck NF \& Khalid M (2007). The effects of GnRH analogue (buserelin) or HCG (Chorulon) on Day 12 of pregnancy on ovarian function, plasma hormone concentrations, conceptus growth and placentation in ewes and ewe lambs. $J$ Anim Repr Sci 102(3-4): 247-257.

22. Nostrand SD, Galton DM, Erb HN \& Bauman DE (1991). Effects of daily exogenous oxytocin on lactation milk yield and composition. J Dairy Sci 74(7): 21192127.

23. Adams HP \& Allen NN (1952). The value of oxytocin for reducing fluctuations in milk and fat yield. J Dairy Sci 35(12): 1117-1120.

24. Carmichael MS, Humbert R, Dixen, J, Palmisano G, Greenleaf W \& Davidson JM (1987). Plasma oxytocin increases in the human sexual response. The J Clin Endoc Metabol 64(1): 27-31.

25. Huang W, Lee SL, Arnason SS \& Sjoquist MATS (1996). Dehydration natriuresis in male rats is mediated by oxytocin. American J Physiol Regul Integ Compar Physiol 270(2): R427-R433.

26. Jezova D, Skultetyova, I, Tokarev DI, Bakos P \& Vigas M (1995). Vasopressin and Oxytocin in Stress a. Annals of the New York Academy of Sci 771(1): 192-203.

27. Mccarthy MM, Mcdonald CH, BROOKS PJ \& Goldman D (1996). An anxiolytic action of oxytocin is enhanced by estrogen in the mouse. J Phys Behave 60(5): 12091215.

28. Ditzen B, Schaer M, GabrielB., Bodenmann G, Ehlert U, \& Heinrichs M (2009). Intranasal oxytocin increases positive communication and reduces cortisol levels during couple conflict. J Biol Psyc 65(9): 728-731.

29. Heinrichs M, Baumgartner T, Kirschbaum C \& Ehlert U (2003). Social support and oxytocin interact to suppress cortisol and subjective responses to psychosocial stress. J Biol Psych 54(12): 1389-1398.

30. Heinrichs M, Dawans B \& Domes, G (2009). Oxytocin, vasopressin, and human social behavior. Frontiers in Neuroendocrinol 30(4): 548-557.

31. Huber D, Veinante P\& Stoop R (2005). Vasopressin and oxytocin excite distinct 
neuronal populations in the central amygdala. J Sci 308(5719): 245-248.

32. Arletta R, Benelli A \& Bertolini A (1989). Influence of oxytocin on feeding behavior in the rat. J. Peptides, 10 (1), 89-93.

33. Deblon N Veyrat-Durebex C, Bourgoin L, Caillon A, Bussier AL Petrosino, S., ...\&Wahli, W. (2011). Mechanisms of the anti-obesity effects of oxytocin in dietinduced obese rats. PloS one, 6(9).

34. Assad NI, Pande, AK, \& Sharma LM (2016). Oxytocin, functions, uses and abuses: a brief review. Theriogenol, Insight-An Inter J Repro all Anim 6(1): 117.

35. Natzke R.P \& Schultz LH (1967). Effect of Oxytocin Injections on Mastitis-Screening Tests and Milk Composition. J of Dairy Sci 50(1): 43-46

36. Ballou LU, Bleck JL, Bleck GT \& Bremel RD (1993). The effects of daily oxytocin injections before and after milking on milk production, milk plasmin, and milk composition. J dairy Sci 76(6): 1544-1549.

37. Seth SD \& Seth V (2009). Text book of Pharmacology. $3^{\text {rd }}$ Ed.

38. Thackare H, Nicholson, HD \& Whittington $K$ (2006). Oxytocin - its role in male reproduction and new potential therapeutic uses. Hum Reprod Update 12(4): 437-448.

39. Marazziti D, Dell'Osso B, Baroni, S, Mungai F, Catena M Rucci P \& Italiani P (2006). A relationship between oxytocin and anxiety of romantic attachment. Clin Practice and Epidemiol in Mental Heal 2(1): 28.

40. Shamay-Tsoory SG, Fischer M, Dvash, J, Harari H, Perach-Bloom N \& Levkovitz Y (2009). Intranasal administration of oxytocin increases envy and schadenfreude (gloating). J Biol Spy 66(9): 864-870.
41. Mavi PS, Pangaonkar GR, Sharma RK, \& Gandotra VK (2004). Effect of Certain Hormones on Reproductive Perormance of Post-Parturient Buffaloes. J Buf 20(2): 193.

42. Armstrong DT \& Hansel W (1959). Alteration of the bovine estrous cycle with oxytocin. J Dairy Sci 42(3): 533-542.

43. Afzal M (2003). Livestock production-A tool for poverty alleviation in Pakistan. Poverty Alleviation Through Sustainable Agriculture Development. F Ullah and F Ullah (eds). NWFP Agriculture University, Peshawar, Pakistan. pp. 59-67.

44. Abbas N\& Zahoor T (2014). Physicochemical Profile of Milk from Oxytocin Injected Buffaloes. Pak Veter J 34(3).

45. Alkass JE \& Merkhan KY (2015). Oxytocin Administration and Its Effect on Milk Yield and Composition of Karadi Ewes. J Anim Sci 1(2): 24-26.

46. Sprain DG, Smith VR, Tyler WJ \& Fosgate OT (1954). The effect on milk and fat production of injections of oxytocin at alternate 14-day periods during lactation. $J$ Dairy Sci 37(2): 195-201.

47. Rigby SL Barhoumi R, Burghardt RC, Colleran P, Thompson JA, Varner DD \& Delp MD (2001). Mares with delayed uterine clearance have an intrinsic defect in myometrial function. J Biol Repro 65(3): 740-747.

48. Siddiqui MM \& Saeed I (2000). Oxytocin and its usage in livestock-a review. J Anim Heal Prod Pak 20: 53-58.

49. Ijaz A \& Aleem M (2006). Exogenous Administration of oxytocin and its residual effects. Pak Vet J 26(2): 99-100.

50. Bhalla, Abhishek, Choudhry \& Preeti (2010). Girls drugged into puberty, sold as prostitutes. India Today, May, 2010. 